\title{
CHARACTERIZATION OF VACUUM EXPLOSIVE WELDED JOINTS BETWEEN TITANIUM AND STAINLESS STEEL FOR VACUUM APPLICATIONS
}

\author{
M. Enav ${ }^{1}$, O. Botstein², D. Ashkenazi3*, A. Stern4,5 \\ ${ }^{1}$ Opto-Mechanical Group, SCD - SemiConductor Devices, P.O. Box 2250, Haifa, Israel \\ ${ }^{2}$ Ika Labs 2006, P.O.B.2107 Tirat Hacarmel 3912002, Israel \\ ${ }^{3}$ School of Mechanical Engineering, Tel Aviv University, Ramat Aviv 6997801, Israel \\ ${ }^{4}$ Department of Mechanical Engineering, Afeka Academic College of Engineering, Tel Aviv, 69107, Israel \\ ${ }^{5}$ Department of Materials Engineering, Ben-Gurion University of the Negev, Beer Sheva 8410501, Israel \\ *Corresponding author's e-mail address: dana@eng.tau.ac.il
}

\begin{abstract}
A two-layered vacuum explosive welded (EXW) plate, consisting of titanium-grade 1/stainless steel 304L (Ti/304L), was investigated for vacuum applications. The interface of the Ti/304L displayed a wavy shape characteristic of the EXW method, which reflects the existence of mass transfer during bonding. The aim of this study was to examine the feasibility of using Ti/304L EXW joints for vacuum application. The Ti/304L EXW plate was examined by non-destructive and destructive metallurgical methods, including visual testing, scanning acoustic testing, light microscopy and metallography, SEM-EDS examination, microindentation hardness measurements, ram tensile test, fractography, and leak testing. According to the metallurgical testing methods, the formation of brittle intermetallic phases took place adjacent to the bonding interface. The intermetallic phases formed at the interface of the Ti/304L, behave as the weakest part in the joint, and determine the brittle type of fracture received under tensile stresses. The measured typical tensile strength of the joint is around $300 \mathrm{MPa}$, similar to that of the Ti 1 alloy. Based on the leak test results, the examined EXW Ti/304L components were found to be feasible for vacuum applications.
\end{abstract}

KEYWORDS: vacuum EXW, solid state welding, metallurgical bonding, stainless steel, titanium, vacuum applications.

\section{ACKNOWLEDGEMENTS}

The authors would like to thank SMT - Shockwave Metalworking Technologies B.V. (Netherlands), for supplying the material for the research. Thanks also go to SCD for supporting the project. Thanks are also due to A. Solomon, Afeka Academic College of Engineering, for her contribution.

\section{REFERENCES}

[1] Crossland B., Explosive Welding of Metals and its Application, Oxford Series on Advanced Manufacturing 2, Clarendon Press, Oxford, 1982.

[2] Rosenthal I., Miriyev A., Tuval E., Stern A. Frage N., Characterization of explosion-bonded Ti-alloy/steel plate with Ni interlayer, Metallography, Microstructure, and Analysis 3.2, 2014, pp. 97-103.

[3] Corigliano P., Crupi V., Guglielmino E., Sili A. M., Full-field analysis of AL/FE explosive welded joints for shipbuilding applications, Marine Structures 57, 2018, pp. 207-218.

[4] Mårtensson N., Schweitz J.Å., Fundamental aspects of formation and stability of explosive welds, Metallurgical Transactions A 16.5, 1985 , pp. 841-852.

[5] Bergeman O. R., Cowan G. R., Holtzman A. H., Experimental evidence of jet formation during explosive cladding, Transactions of the Society of Mining Engineers of AIME 236, 1966, pp. 646-653.

[6] Shribman V., Bahrani A. S., Crossl B., The techniques and the mechanism of explosive welding. Production Engineer 48.2, 1969, pp. 69-83.

[7] McKee F. A., Crossland B., Further experiments on the mechanism of explosive welding, Proceedings of the 5th International Conference of High Energy Rate Fabrication, June 24-26, Denver University, Denver, CO, 1975, pp. 1-25.

[8] Nobili A., Banker J. G., Proceedings of Reactive Metals in Corrosive Applications Conference, September, Wah Chang, Albany, OR, 1999, pp. 83-88. 
[9] Raghukandan K., Analysis of the explosive cladding of Cu-low carbon steel plates, Journal of Materials Processing Technology 139, 2003, pp. 573-577.

[10] Raghukandan K., Hokamoto K., Manikandan, P., Optimization of process parameters in explosive cladding of mild steel and aluminum, Metals and Materials International 10.2, 2004, pp. 193-197.

[11] Kahraman N., Gülenç B., Findik F., Joining of titanium/stainless steel by explosive welding and effect on interface, Journal of Materials Processing Technology 169.2, 2005, pp. 127-133.

[12] Öberg Å., Mårtensson N., Schweitz J-Å., Fundamental aspects of formation and stability of explosive welds, Metallurgical Transactions A $16.5,1985$, pp. $841-852$.

[13] Blatter A., Peguiron D. A., Explosive joining of precious metals, Gold Bulletin, 31.3, pp. 93-98.

[14] Yan Y. B., Zhang Z. W., Shen W., Wang J. H., Zhang L. K., Chin B. A., Microstructure and properties of magnesium AZ31Baluminum 7075 explosively welded composite plate, Materials Science and Engineering: A, 527.9, 2010, pp. 2241-2245.

[15] Palmer T. A., Elmer J. W., Brasher D., Butler D., Riddle R., Development of an explosive welding process for producing high-strength welds between niobium and 6061-T651 aluminum, Welding Journal 85.11, 2006, pp. 252-263.

[16] Krebsbach J., Krebsbach I., Explosion Bonding of Titanium and Alloyed Steel. Adaptive Coatings Technologies AB95015, 1996.

[17] Krebsbach J., Krebsbach I., 1999. Explosively Bonded Armor Materials (No. AB95015). Adaptive Coatings Technologies AB95015, 1999.

[18] Song J., Kostka A., Veehmayer M., Raabe D., Hierarchical microstructure of explosive joints: Example of titanium to steel cladding. Materials Science and Engineering: A 528.6, 2011, pp. 2641-2647.

[19] Jiang H. T., Yan X. Q., Liu J. X., Duan X. G., Effect of heat treatment on microstructure and mechanical property of Ti-steel explosiverolling clad plate, Transactions of Nonferrous Metals Society of China 24.3, 2014, pp .697-704.

[20] Zhang Y., Babu S. S., Prothe C., Blakely M., Kwasegroch J., LaHa M., Daehn G. S., Application of high velocity impact welding at varied different length scales, Journal of Materials Processing Technology 211.5, 2011, pp. 944-952.

[21] Lysak V. I., Kuzmin S. V., Lower boundary in metal explosive welding. Evolution of ideas, Journal of Materials Processing Technology 212.1, 2012, pp. 150-156.

[22] Chao R. M., Yang J. M., Lay S. R., Interfacial toughness for the shipboard aluminum/steel structural transition joint, Marine Structures $10.5,1997$, pp. 353-362.

[23] Tricarico L., Spina R., Sorgente D., Brandizzi M., Effects of heat treatments on mechanical properties of Fe/Al explosion-welded structural transition joints, Materials \& Design 30.7, 2009, pp. 2693-2700.

[24] Manikandan P., Hokamoto K., Deribas A. A., Raghukandan K., Tomoshige R., Explosive welding of titanium/stainless steel by controlling energetic conditions, Materials transactions 47.8, 2006, pp. 2049-2055.

[25] Findik F., Recent developments in explosive welding, Materials \& Design 32.3, 2011, pp. 1081-1093.

[26] Paul H., Faryna, M., Prażmowski M., Bański R., Changes in the bonding zone of explosively welded sheets. Archives of Metallurgy and Materials 56.2, pp. 463-474.

[27] Gloc M., Wachowski M., Plocinski T., Kurzydlowski K. J., Microstructural and microanalysis investigations of bond titanium grade1/low alloy steel st52-3N obtained by explosive welding. Journal of Alloys and Compounds 671, 2016, pp. 446-451.

[28] Wang T., Zhang F., Li X., Jiang S., Feng J., Interfacial evolution of explosively welded titanium/steel joint under subsequent EBW process. Journal of Materials Processing Technology 261, 2018, pp. 24-30.

[29] Becher O., Nahmany M., Ashkenazi D., Shribman V., Stern A., On bond formation in magnetic pulse welded joints. The Annals of Dunarea De Jos University of Galati Fascicle XII: Welding Equipment and Technology 25, 2014, pp. $23-28$.

[30] Mousavi S. A., Sartangi P. F., Experimental investigation of explosive welding of cp-titanium/AISI 304 stainless steel, Materials \& Design 30.3, pp. 459-468. 